\title{
Academics' Societal Engagement in the Humanities and Social Sciences: A Generational Perspective from Argentina, Germany, Portugal, and Sweden
}

\author{
Christian Schneijderberg ${ }^{\mathrm{a}}$ (D), Anders Broström ${ }^{\mathrm{b}}$ (i), \\ Teresa Cavalho $^{\mathrm{d}}$ (1), Lars Geschwind ${ }^{\mathrm{d}}$ (1) , Monica Marquina ${ }^{\mathrm{e}}(\mathbb{1})$, \\ Lars Müller ${ }^{\mathrm{a}}$ (1) and Nicolas Reznik ${ }^{\mathrm{f}}$ (1) \\ ${ }^{a}$ International Centre for Higher Education Research, University of Kassel, Moenchebergstr. 17, \\ 34109 Kassel, Germany. \\ E-mail: schneijderberg@incher.uni-kassel.de \\ ${ }^{\mathrm{b}}$ KTH Royal Institute of Technology, 10044 Stockholm, Sweden. \\ ${ }^{c}$ University of Aveiro and CIPES, Campus Universitário de Santiago, 3810-183 Aveiro, Portugal. \\ ${ }^{\mathrm{d}}$ Department of Learning in Engineering Sciences, KTH Royal Institute of Technology, Osquars Backe \\ 31, 10044 Stockholm, Sweden. \\ e Núcleo Interdisciplinario de Formación y Estudios para el Desarrollo de la Educación (NIFEDE), \\ Universidad Nacional de Tres de Febrero - CONICET, Buenos Aires, Argentina. \\ ${ }_{\mathrm{f}}^{\mathrm{f}}$ úcleo Interdisciplinario de Formación y Estudios para el Desarrollo de la Educación (NIFEDE), \\ Universidad Nacional de Tres de Febrero, Buenos Aires, Argentina.
}

Political discourse and policy reforms worldwide have highlighted the importance of promoting the knowledge economy by stimulating academics' societal engagement (ASE). Such narratives partly aim at influencing academics' attitudes and behaviors. Earlier work that has investigated such influence has tended to overlook the development in humanities and social science, and focused on science, technology, engineering, and mathematics fields. This paper contributes to filling this gap. Based on the assumption that academics' views are, to a significant extent, shaped during their early years in academia, we investigate whether there are generational differences in attitudes to ASE. Four different higher education systems, including both Napoleonic and Humboldtian models, are investigated: Germany, Sweden, Portugal, and Argentina. Our analysis of the results of the international Academic Profession in the Knowledge Society survey reveals marked country-level differences in the way academics perceive the importance of ASE activities. Overall, there is no strong evidence that the current generation of HSS academics has very different attitudes to ASE than previous

Electronic supplementary material The online version of this article (https://doi.org/10.1057/ s41307-020-00218-6) contains supplementary material, which is available to authorized users. 
generations. We do, however, find indications that post-2006 academics are more likely to consider ASE activities from an instrumental perspective.

Higher Education Policy (2021) 34, 42-65. https://doi.org/10.1057/s41307-020-002186; published online 14 January 2021

Keywords: academics' societal engagement; academic generations; knowledge economy; humanities; social sciences

\section{Introduction}

During the past few decades, academics' societal engagement (ASE) has received unprecedented attention from key stakeholders of academia. For example, the Organization for Economic Cooperation and Development (OECD) played an important role in shaping policy agendas that promote ASE activities, such as patenting, licensing, and spin-offs, through championing the National Innovation Systems approach (e.g., Lundvall, 1992; OECD, 1997). This discourse leveraged higher education (HE), innovation, and science studies (e.g., Arbo and Benneworth, 2007) to promote ideas about research, teaching, knowledge, and technology transfer as central drivers of economic growth and prosperity in the knowledge economy (KE) (e.g., Godin, 2006; Henriques and Larédo, 2013; OECD, 1996). KE policies are also supported by other international organizations (e.g., World Bank, 2002) and have trickled down via both regional (e.g., APEC, 2000; EC, 2005; CEPAL, 1992) and national HE, innovation, and science policies in, for example, Argentina (e.g., Marquina et al., 2015, 2017), Germany (e.g., Hüther and Krücken, 2018), Portugal (e.g., Carvalho, 2012), and Sweden (e.g., Benner and Sandström, 2000). KE policies and related ideology have also had a significant impact on the governance of higher education institutions (HEIs) (e.g., Geuna and Muscio 2009; Pinheiro et al., 2019).

While changes in governance are generally expected to lead to changes in social behavior, there is no consensus in the literature regarding how governance reforms related to KE policies have changed academics' behavior patterns (de Rijcke et al., 2016; Gläser, 2019). In general, studies have shown that ASE is, to a large extent, driven by the motivations of individual academics and their networks of relationships with industry and other sectors of society (e.g., Perkmann et al., 2013; Thune et al., 2016).

In this study, we investigate the extent to which normative KE policy expectations are reflected in the views and attitudes of individual academics concerning ASE. We focused on what Biglan (1973) refers to as the soft sciences: the humanities and social sciences (HSS). Whereas ASE in the hard sciences or 
STEM has been widely studied (e.g., Perkmann et al., 2013), considerably less research has investigated ASE in HSS (e.g., Olmos-Peñuela et al., 2013). The unique nature of HSS research (e.g., in terms of the alignment between stakeholder interests and academic norms; Perkmann et al., 2011), and the primarily noncommercial character of HSS ASE (Molas-Gallart and Tang, 2011) make it hard to predict how KE policy expectations may have affected HSS academics.

Guided by the scarce literature on HSS ASE (e.g., Abreu et al., 2009; Schneijderberg and Teichler, 2012), we adopt a definition of ASE activities that goes beyond research commercialization to also include a broad range of other informal activities, focusing on, for example, social contributions in regional arenas (e.g., Benneworth, 2013).

According to Shaw (2005), both time and space affect the definition of generations because of the subjects' presence in a delineated historical period and socialization in terms of values, beliefs, and attitudes, as well as the perceived demands of a HE system and academics' work in HEIs. Against this background, we argue that academics entering into academia in more recent years are likely to be more greatly affected by KE-policy rhetoric than their colleagues whose socialization into academia took place earlier. Our primary interest in this study is to investigate differences between generations of HSS academics in how the role of ASE in academic life is being conceived. We define three generations of HSS academics according to their date of initial entry into academia (pre-1995, between 1995-2006, and post-2006) to study whether more recent generations of academics, who entered academia after the introduction of KE policies, have embraced ASE as central to academic life.

We used the 2018 Academic Profession in Knowledge Society (APIKS) survey to investigate academics' attitudes toward their ASE activities in Argentina, Germany, Portugal, and Sweden. In the following section, we describe theories of academic socialization and define the generations used in this study by reference to the evolution of KE policies. Next, we describe and justify our sample, then outline the data, methods, and variable descriptions. Finally, we present and discuss our results and provide conclusions.

\section{Academic Generations and Global Knowledge Economy Policies}

\section{Theorizing socialization and academic generations}

Many researchers have studied social change by looking at and comparing cohorts (Ryder, 1965) or generations (Shaw, 2005). From a life-course perspective (Marquina et al., 2015), generations are defined by specific historical events within a certain trajectory, such as an academic career; such events have specific influences on professional development and identity formation. Accordingly, differences in terms of values, beliefs, and attitudes can be expected to arise 
between generations of academics due to, for example, the shifting expectations and perceived demands of the HE system and HEIs, which affect the situated socialization of, in particular, junior scholars (Shaw, 2005).

The socialization of the members of a specific age group is considered the basis for members' understanding of themselves as part of a single generation of academics, with specific routines and a shared understanding of academics' work in research, teaching, and complementary ASE (Austin, 2002; Marquina et al., 2015). According to Shaw (2005), socialization also influences the construction of academic careers as a processual interplay between individual academics and their senior colleagues in specific HEI settings. Especially in the beginning of junior academics' careers (e.g., their first academic position and dissertation research), senior academics act as teachers and role models, contributing to both their knowledge and skills and the formation of their identity (Austin, 2002; Pearson and Brew, 2002; Schneijderberg, 2019). More abstractly, socialization theory identifies two distinct structuring dynamics of (academic) teaching and learning: the development of personality, knowledge, and skills, and the establishment and maintenance of a bond with a specific (academic) community (Grundmann, 2006; see also Becher and Trowler, 2001).

Academics' values, beliefs, and attitudes are subject to professional autonomy and control (Freidson, 2001; Parsons, 1968), but are also influenced by academia's oligarchic structures and managerial practices (Brennan, 2010; Pusser, 2008). According to Clark $(1983,122)$, the academic oligarchy comprises "the imperialistic thrust of modes of authority [...] in the way that personal and collegial forms, rooted in the disciplinary bottom of a system, work their way upward to have an important effect on enterprise and then finally system levels." On the systems level, the structures of academic authority have a reciprocal relationship with $\mathrm{HE}$ and scientific policy structures. Accordingly, substantial changes in the rhetoric and direction of policy can be expected to generate differences in the values, beliefs, attitudes, and perceived demands of academics of different generations.

\section{Innovation, implementation, and adaptation of global KE policy}

The socio-political process studied in this article is the introduction of ideas about scientific knowledge and education as key building blocks of a "knowledge economy" (KE), and policy changes that seek to leverage HEI activities to such ends. This process is supposed to influence not only HEI governance but also the functioning of the academic profession and mechanisms of promotion in academic careers. We consider the spread of the core KE idea-the complementarity of education, research, and innovation in ASE - as social innovation. According to innovation theory, any innovation includes a phase of social and technological implementation, which is followed by the adaptation phase, when adoption reaches 
a critical mass (Rogers, 1983). Rogers' (1983) elaborate summary of the diffusion of innovations makes clear that defining the implementation and adaptation phases is not an exact science and needs to take context into account. In this case, the relevant context was academics' socialization, as discussed in the previous section. Accordingly, to answer our research question concerning the extent to which KE policy expectations affect academics' views and attitudes, we first needed to delineate the implementation and adaptation phases of KE policy by reference to the timing of an event (e.g., Aagaard and Schneider, 2016).

The diffusion of KE ideas can be understood as following the pattern of idea dispersion, implementation (i.e., the translation of KE ideas into policy initiatives), and adaptation described by Rogers (1983, 11). Following Godin (2006), we selected 1994 as the threshold for defining the pre- and post-KE generations. Various authors have also provided an overview of the implementation of $\mathrm{KE}$ policies and the engagement of major international organizational players, such as the OECD, the EU, and the Economic Commission for Latin America and the Caribbean (CEPAL), in their development (e.g., Gorostiaga and Tello, 2011). According to these authors, the KE was first put on the global political agenda by the publications Knowledge-based Economy (OECD, 1996) and National Innovation Systems (OECD, 1997). Other global economic organizations, such as the World Bank (2002), subsequently contributed to KE policy-making. In Latin America, CEPAL, one of the five regional commissions of the United Nations, advocated for KE policy in the early 1990s, with an emphasis on linking equality in education with the necessary transformation of production. Around the turn of the millennium, the trickle-down application of the KE concept to regional policies began, with, for example, the Asia Pacific Economic Cooperation group (APEC, 2000). In Europe, the 2000 Lisbon Agenda defined Europe's goal as "strengthen[ing] the three poles of its knowledge triangle: education, research and innovation", (EC, 2005, 152). By 2006, the KE policy agenda was influential in national debates in Argentina, Germany, Portugal, and Sweden, and informed the formation of policy. The most obvious national manifestations of KE policy are the use of indicators such as patents and licenses for academics' performance evaluations, as well as the mandatory inclusion of ASE activities in grant applications and funding schemes.

\section{The peak socialization phase of academic careers in Argentina, Germany, Portugal, and Sweden}

In addition to the evolution of KE policy, our definition of generations also takes into account the nature of academic career progression. Building on the idea of socialization in an academic's life course discussed in section "Theorizing socialization and academic generations", we consider that socialization is most 
intensive in the early stages of an academic career. In this section, we discuss the time-span that should separate different generations of academics.

In Argentina, obtaining a doctoral degree was not historically a requirement for an academic career. However, reforms during the 1990s codified in law that having a PhD would gradually be introduced as a prerequisite for academic positions. Various policies were implemented to incentivize compliance with this change, such as scholarships or leave of absence for academics to finalize their PhD. A 2017 study found that, of the total number of academics with a doctoral degree, 85\% had obtained it between 1990 and 2007 (Marquina et al., 2017). Currently, only $13 \%$ of university teachers have a doctoral degree, with $10 \%$ holding a master's degree or similar qualification (UPS, 2020). Although no timeline for the $\mathrm{PhD}$ requirement was formally established, the duration of doctoral studies varies from 4 to 10 years according to discipline, following an undergraduate degree ${ }^{1}$ that lasts between 5 and 6 years. Therefore, the socialization phase in Argentina is related more to the accumulation of teaching experience and scientific production than to the acquisition of higher academic degrees, especially in HSS fields. If academics have a Ph.D., they can more easily obtain promotions to higher positions, which range from teaching assistant to professor. On the other hand, the possibilities of promotion are limited by the availability of positions in HEis.

In Germany, the qualification phase for junior academics is roughly 12 years. By law (Wissenschaftszeitvertragsgesetz, 2016), junior academics have 6 years to finish their $\mathrm{PhD}$ and another 6 years to write their Habilitation (the so-called second qualification book, in addition to the published doctoral thesis) or present comparable achievements in a postdoc, tenure-track/junior professor position. In Germany, the median age for obtaining a master's degree is about 26 for women and almost 27 for men. Accordingly, junior academics are usually about 33 when they finish their PhD and start their postdoc phase, a step, which marks the end of the socialization process and the establishment of their values, beliefs, attitudes, and perceptions of their institute's demands (Austin, 2002; Shaw, 2005). The mean and median age for becoming a professor is 40 (GFSO, 2018b).

In Portugal, the qualification requirements underwent substantial changes in 2009 (Cardoso et al., 2019). Before the 2009 reform, access to an academic career was possible with a bachelor's degree, although obtaining a permanent position was conditional on holding a doctoral degree. Since 2009, a doctoral degree is the minimum qualification for beginning an academic career, with academics being able to obtain a permanent position after a 5-year probationary period. Advancement to more senior, tenure-track positions (associate and full professor) is conditioned upon selection to an open vacancy through an international recruitment process. To be eligible for a professor position, an academic must have the title agregação (equivalent to the German Habilitation), which is awarded based on the merit of their CV and evaluation of a public lecture. Since obtaining a professor position requires the existence of an open vacancy, the length of time necessary to 
obtain such a position differs across HEIs and disciplines. Although there are no publicly available statistics concerning this issue, it is known that it can take between 10 and 20 years after being awarded a $\mathrm{PhD}$ to gain a professor or associate professor position.

In Sweden, getting a $\mathrm{PhD}$ requires 4 years' full-time study. After that, an increasing number of $\mathrm{PhD}$ holders pursue a postdoc or a fixed-term position as a researcher, primarily in externally funded positions. The tenure-track position of assistant professor (biträdande lektor) has gradually replaced the appointment (forskarassistent), which did not include the possibility of tenure (Henningsson et al., 2018). Assistant professorships are research-oriented, with typically 70-80\% of time devoted to research and the remainder to teaching. The most common position, which is tenured, is senior lecturer/associate professor (lektor). This was originally a teaching-only role but, over time, it has become the standard midcareer position, comprising primarily teaching and some research. Since 1999, it has been possible to be promoted to full professor based on merit, normally 5 to 10 years after becoming a senior lecturer. Sweden has also retained the title docent, equivalent to the German Habilitation (Numhauser-Henning et al., 2007). Since the Swedish HE system is decentralized and differs across HEIs, there are no national statistics available regarding the average time required to become an associate professor or professor. Obtaining tenure typically takes 10 to 12 years: 4 years as a $\mathrm{PhD}$ student, another 2 years as a postdoc, and 4 to 6 years as an assistant professor.

Based on the periods of academic socialization in Argentina, Germany, Portugal, and Sweden, as well as the diffusion of KE policies discussed in previous sections, we differentiate the three academic generations:

a. Post-2006 generation (i.e., first HEI employment in 2007 or later)

b. 1995--006 generation

c. Pre-1995 generation

As mentioned earlier, defining innovation diffusion phases is not an exact science. In the context of an academic lifetime, the selected 12-year periods captured the socialization peaks of the two post-KE academic generations (i.e., 1995-2006 and post-2006). In sum, we were able to study a period of 24 years, which correlates with other studies on the diffusion of social innovation. For example, Aagard and Schneider (2016) found that macro-level funding policies take 25 years to trickle down to micro-level behavior. Rogers' $(1983,165)$ examination of science-related examples of diffusion also suggested a substantial time-span of about 20 years. 


\section{Three academic generations and their responses to KE policies: Hypotheses}

As discussed above, academic socialization is a cognitive and social process that structures academic careers and includes identification with the ideas and norms of academic work and disciplinary specificities related to academic work (research, teaching, and ASE), as well as the formation of identity in an organizational environment. Based on this definition, we assumed that the KE policies supporting ASE had distinct socialization effects on the core academic activities of research and teaching, and considered the period around 2000 as the most important in terms of KE policy implementation. For that reason, we expect to find that attitudes toward ASE were most influenced by KE ideas among the post-2006 generation. We focus on how this generation differ from the pre-1995 generation, although we also investigated how the 1995-2006 generation related to the others. Accordingly, we assume in Hypothesis 1 (H1) that academics in the post-2006 generation (i.e., KE policy adaptation phase) assign greater importance to ASE in their research and teaching activities:

H1a Compared to the pre-1995 and 1995-2006 generations, academics in the post-2006 generation perceive ASE activities as being more important to their research activities.

H1b Compared to the pre-1995 and 1995-2006 generations, academics in the post-2006 generation perceive ASE activities as being more important to their teaching activities.

Assuming the increasing importance of ASE for professional academic work, Hypothesis 2 (H2) stated that academics in the post-2006 generation assign greater importance to ASE in terms of their reputation and career:

H2a Compared to the pre-1995 and 1995-2006 generations, academics in the post-2006 generation perceive ASE activities as being more important to their reputation.

H2b Compared to the pre-1995 and 1995-2006 generations, academics in the post-2006 generation perceive ASE activities as being more important to their career.

To the extent that academics' attitudes toward what constitutes appropriate behavior in research and teaching have internalized KE policy rhetoric, we expected academics to consider ASE activities as important not only to themselves but also to their peers. Due to the greater adaptability of junior academics, we expect scholars still in their socialization phase to embrace KE ideas to a greater extent than their more senior colleagues. We thus posit in Hypothesis 3 (H3) that, compared to the pre-1995 and 1995-2006 generations, academics in the post-2006 generation perceive ASE activities as being more important for the development of 
Christian Schneijderberg et al.

Academics' Societal Engagement in the Humanities and Social Sciences

50

their discipline. Recognizing modern HEIs as more organized corporate entities than the pre-1995 and 1995-2006 generations, we finally suggest in Hypothesis 4 (H4) that academics in the post-2006 generation perceive ASE activities as more important to the mission of their HEI.

\section{Sampling}

To test H1-4, we used APIKS 2018 data from Argentina, Germany, Portugal, and Sweden. The sample comprises diverse cases (Seawright and Gerring, 2008), which enable a large-n in small-n cross-country comparison (Fig. 1 in Schneijderberg and Götze, 2021; see also Ebbinghaus, 2005; Smelser, 2003). We used a confirmatory technique, as it allowed us to test the relationships between the dependent variable (ASE-importance) and independent variables (as shown in Table 2).

The selection of these four countries allowed for a systematic comparison of the impact of KE policy on the importance of ASE among HSS academics of different generations in four diverse contexts: two smaller (i.e., Portugal and Sweden) and two larger HE systems (i.e., Argentina and Germany; Table ESM1 in Electronic Supplementary Material). Given journal article word limitations, selecting more cases would not have been feasible. The HE system traditions of Argentina and Portugal are defined as Napoleonic Models, and the German and Swedish cases as Humboldtian Models (Sam and van der Sijde, 2014). The countries' HE traditions also manifest in different socialization phases and career structures. Focusing on four dimensions of academic labor markets (i.e., candidate selection principles, duration and type of socialization, career advancement, and salaries and work models) and three characteristics of HEIs (i.e., university-faculty relationships, labor division, and hierarchies), Enders and Musselin (2008) defined the ideal shapes of national academic labor markets and their associated career paths. The French case, representing the Napoleonic model, is classified as a "protective pyramid" and the German case as the "survivor" model (Enders and Musselin, 2008, 134-135). According to socialization theory, the Humboldtian and Napoleonic models' specific structuring dynamics and underlying personal and social orientations enable academics to pursue in different ways the goals of, first, establishing and maintaining a bond to a professional community and, second, developing a personality, knowledge, and skills for the independent conduct of life (e.g., Bronfenbrenner, 1979; Grundmann, 2006).

Considering differences in socialization, the context of the Napoleonic model, with its focus on the professional HE of a nation's functional elite (Sam and van der Sijde, 2014), implies closer networks of academics and non-academic partners in Argentina (Marquina et al., 2015) and Portugal (Cabrito, 2004). In contrast, the elite networks of academics and non-academic cooperation partners in the Humboldtian HE systems in Germany (Hartmann 2018) and Sweden (Edling 
et al., 2013) can be expected to be more heterogeneous. First, the tradition of academic freedom of research, teaching, and learning does not naturally encourage ASE. Secondly, university education in many HSS fields is not designed for a specific professional vocation, with some exceptions including teacher education, law, business and economics, and religious studies. HSS degrees are historically more teaching-based than in other areas, such as STEM and medicine (Nunes, 1988).

Sam and van der Sijde (2014) also differentiated between Humboldtian and Napoleonic HE governance models. Despite the models sharing a centralized system of governance, Humboldtian governance is horizontal (i.e., powerful chairs at the same level), whereas Napoleonic governance is vertical or hierarchical. Acknowledging the difficulties of effect attribution (Gläser, 2019), the KE-driven governance reforms seem to transcend HE traditions. For example, Paradeise et al. (2009) concluded their comparative study on largely resource-driven policy reforms in European HE systems by noting that the effects of such reforms did vary between countries with Humboldtian and Napoleonic systems. The policy reforms impacted several core concepts within HE, such as basic academic principles, the organization of research, and modification of career paths. For example, in Germany, the Humboldtian ideals of the HE system (e.g., unity of research and teaching, research and teaching in solitude and freedom, and the university as a community of teachers and learners) have been challenged by governmental reforms influenced by the doctrine of New Public Management, including KE policies. For example, since the mid-1990s, the creation of research units and, more recently, changes in researchers' career paths have disrupted the principle of research and teaching unity (Müller and Schneijderberg, 2020). Similarly, in Portugal, STEM policies have focused on the national need to orient scientific knowledge to the economy since the mid-1990s (Santiago et al., 2015). In addition, to promote the country's economic competitiveness by using ASE to build a stronger relationship with enterprises, research centers were created and given greater autonomy than other academic units (Heitor and Horta, 2011).

The deviation from the traditional HE model through policy reforms has been even more striking in Argentina and Sweden. In Argentina, the university system evolved under a Napoleonic model, with programs oriented to training of professionals. During the 1960s, the development of research and knowledge for their own sake began to gain prominence, although this change was limited to a small section of the HE system. A significant difference with Napoleonic HEIs in Europe was the strong autonomy of universities with respect to the state, a division that was granted constitutional status in 1994 (Marquina, 2011). Historically, Sweden's HE system has generally followed the Humboldtian model, with strong links to the German system for a long period. However, the system is increasingly oriented toward the US, for instance through the establishment of a tenure-track career system. The autonomy of Swedish universities is codified in the Higher 
Christian Schneijderberg et al.

Academics' Societal Engagement in the Humanities and Social Sciences

52

Education Act and Higher Education Ordinance, as are the links between teaching and research and the idea that teaching should be based on research and proven practice. However, KE policies have also been implemented across the HE sector, albeit with some resistance from HSS scholars and the older universities (Andrén, 2013).

\section{Data, Methods, and Variables}

\section{Academics' ASE activities in Argentina, Germany, Portugal, and Sweden}

The APIKS survey, an internationally harmonized instrument to investigate academic working life across the world, was conducted in 2018 (Table ESM1 in the Electronic Supplementary Material). In one section of the survey, academics were asked to provide information about their engagement in a range of ASE activities and their attitudes to such activities.

To provide a brief overview of academics' ASE activities, the activities were clustered based on an exploratory factor analysis conducted on the German data. The resulting four factors were similar to those identified and used in other studies (e.g., Thune et al., 2016):

1. Commercialization: Patenting, spin-offs, evaluations, contract research, constancy, curriculum development, and continuing education.

2. Industrialization: Joint research, access to external resources, and other forms of organized ASE.

3. Dissemination: Voluntary work, public lectures, presentations to external audiences, and external board memberships.

4. Supervision: Joint supervision of internships, and bachelor, master, and Ph.D. theses.

Table 1 shows the share of respondents in each generation and from each country that reported having participated in at least one ASE activity in the last three years. Overall, our data indicate that dissemination activities were the most prominent in HSS. In comparison to Germany, Portugal, and Sweden, the level of ASE activity in Argentina was rather moderate.

In general, the share of academics engaging in ASE was higher among the pre2006 generations. This pattern of increased activity with greater employment time is consistent with the findings of previous studies (e.g., Link et al., 2008; MeyerKrahmer and Schmoch, 1998). The pattern can be explained by the accumulation of networks and knowledge over time, but also by the differences in status between professors (who were primarily represented in the pre-1995 and 1995-2006 generations) and academics in their pre- and postdoctoral qualification phase (who were primarily represented in the post-2006 generation). The latter explanation 
Christian Schneijderberg et al.

Table 1 ASE activities in Argentina, Germany, Portugal, and Sweden across different generations of academics in HSS (in percentages, with number of observations in brackets; multiple answers possible). Source: APIKS-survey 2018

\begin{tabular}{llllll}
\hline Country & $\begin{array}{l}\text { ASE Activities } \\
\text { Index }\end{array}$ & $\begin{array}{l}\text { Post-2006 } \\
\text { Generation }\end{array}$ & $\begin{array}{l}\text { 1995-2006 } \\
\text { Generation }\end{array}$ & $\begin{array}{c}\text { Pre-1995 } \\
\text { Generation }\end{array}$ & Total \\
\hline Argentina & Commercialization & $29.63(72)$ & $32.14(54)$ & $41.44(46)$ & $32.95(172)$ \\
& Industrialization & $14.40(35)$ & $18.45(31)$ & $20.72(23)$ & $17.05(89)$ \\
& Dissemination & $34.98(85)$ & $45.83(77)$ & $49.55(55)$ & $41.57(217)$ \\
& Supervision & $12.35(30)$ & $17.86(30)$ & $23.42(26)$ & $16.48(86)$ \\
Germany & Commercialization & $45.07(466)$ & $60.58(252)$ & $63.54(183)$ & $51.84(901)$ \\
& Industrialization & $50.29(520)$ & $50.48(210)$ & $51.74(149)$ & $50.58(879)$ \\
& Dissemination & $68.96(713)$ & $84.38(351)$ & $83.68(241)$ & $75.09(1305)$ \\
& Supervision & $58.41(604)$ & $63.70(265)$ & $68.75(198)$ & $61.39(1067)$ \\
Portugal & Commercialization & $54.38(87)$ & $54.25(217)$ & $57.35(195)$ & $55.44(499)$ \\
& Industrialization & $64.38(103)$ & $65.25(261)$ & $65.88(224)$ & $65.33(588)$ \\
& Dissemination & $75.63(121)$ & $82.25(329)$ & $85.88(292)$ & $82.44(742)$ \\
& Supervision & $50.63(81)$ & $60.75(243)$ & $53.24(181)$ & $56.11(505)$ \\
Sweden & Commercialization & $51.61(48)$ & $54.67(193)$ & $58.91(281)$ & $56.55(522)$ \\
& Industrialization & $35.48(33)$ & $47.31(167)$ & $41.09(196)$ & $42.90(396)$ \\
& Dissemination & $67.74(63)$ & $71.67(53)$ & $71.07(339)$ & $70.96(655)$ \\
& Supervision & $21.51(20)$ & $20.40(72)$ & $25.37(121)$ & $23.08(213)$ \\
\hline
\end{tabular}

applies particularly well to Germany; the German HE system has strong status differences, with only $19 \%$ of all academics holding the rank of professor (GFSO, 2018a), and the generational differences were more pronounced in the German data than in the other countries. The Swedish results showed the only noteworthy deviation from this pattern (in the industrialization category). In this sample, the oldest generation (pre-1995) is less frequently engaged in organized ASE activities than the mid generation of academics (1995-2006).

\section{Methodology}

Our main variables of interest are a set of assessments of academics' perceptions of the importance of their ASE activities to six aspects of academic work (as shown in the first section of Table 2). The outcomes were measured on a 5-point Likert-scale (from 'not important' to 'very important'). In the APIKS survey, these questions were only asked of academics who indicated that they partake in at least one ASE activity, as shown in Tables 1 and ESM2.

Assessments of the importance of ASE activities can be expected to be related to additional factors beyond generational differences alone. Accordingly, to test our hypotheses about how these assessments differ between generations, we ran multivariate regression models for each of the six outcome variables, separately for each country. Our dependent variables were measured as ordered categories. We, therefore, applied the ordinal logistic estimator (Long and Freese, 2014, 309ff, 
Christian Schneijderberg et al.

Academics' Societal Engagement in the Humanities and Social Sciences

54

Table 2 Variables used in regression analysis.

\begin{tabular}{|c|c|c|}
\hline Name & Description & Range \\
\hline \multicolumn{3}{|l|}{ Dependent variables } \\
\hline Research & $\begin{array}{l}\text { Importance of ASE for } \\
\text { academics' research }\end{array}$ & 1 (Not important) -5 (Very important) \\
\hline Teaching & academic's teaching & \\
\hline Reputation & academics' reputation & \\
\hline Career & $\begin{array}{l}\text { academics' career } \\
\text { advancement }\end{array}$ & \\
\hline Discipline & academics' discipline & \\
\hline HEImission & $\begin{array}{l}\text { mission of academics' } \\
\text { HEI }\end{array}$ & \\
\hline \multicolumn{3}{|c|}{ Independent variables } \\
\hline & Individual characteristics & $1=$ professor \\
\hline Rank & $\begin{array}{l}\text { Professors (professor and } \\
\text { associate professor; } \\
\text { senior faculty) } \\
\text { Non-professors and } \\
\text { junior academics }\end{array}$ & $\begin{array}{l}0=\text { non-professor (assist. prof, lecturer, researcher, } \\
\text { etc.) }\end{array}$ \\
\hline Gender & Gender & $\begin{array}{l}0=\text { male } \\
1=\text { female }\end{array}$ \\
\hline \multirow[t]{2}{*}{ ExternalWork } & $\begin{array}{l}\text { Work experience outside } \\
\text { of universities in } \\
\text { government, industry, } \\
\text { and self-employment }\end{array}$ & $\begin{array}{l}0=\text { no } \\
1=\text { yes }\end{array}$ \\
\hline & $\begin{array}{l}\text { Time budget (average per } \\
\text { week) }\end{array}$ & $\begin{array}{l}0-1 \text { (percentage of time dedicated to ASE in relation } \\
\text { to other functions. }(100 \%=\text { time devoted to }\end{array}$ \\
\hline TimeBudget & $\begin{array}{l}\text { for ASE } \\
\text { Research characteristics }\end{array}$ & $\begin{array}{l}\text { research }+ \text { teaching }+ \text { management }+\mathrm{ASE}+\text { other }) \\
1(\text { Not at all })-5(\text { Very much })\end{array}$ \\
\hline Applied & $\begin{array}{l}\text { Applied/practically } \\
\text { oriented }\end{array}$ & \\
\hline Inter-/ & Inter-/Multidisciplinary & \\
\hline \multicolumn{3}{|l|}{ Multidisciplinary } \\
\hline & HEI expectation & 1 (Not at all) -5 (To a very high extent $)$ \\
\hline FundingExpectations & $\begin{array}{l}\text { Raising substantial } \\
\text { amounts of external } \\
\text { funds }\end{array}$ & \\
\hline
\end{tabular}

chapter 7). We ran two regression models for each outcome variable: one including only controls and one including the main explanatory variable 'Generation' plus the control variables.

To reduce the loss of observations per country due to partial non-response issues, we used only a limited number of controls. Control variables are selected based on the modified analytical framework of Perkmann et al. (2013; Fig. 1 in Schneijderberg and Götze, 2020). As presented in Table 2, control variables include academic rank, external work experience, and gender, which were of 
Christian Schneijderberg et al.

particular relevance to the tests of $\mathrm{H} 1$ and $\mathrm{H} 2$. Additional controls are the selfreported research characteristics of applied research and inter-/multi-disciplinarity, ${ }^{2}$ academics' ASE time allocation, and HEI funding expectations. The latter control captures the organizational level (relevant to $\mathrm{H} 4$ ) and the research characteristics are related to the systems level of the discipline (relevant to H3).

\section{Results}

\section{Descriptive results}

Table ESM2 reports the descriptive results of our analysis. Overall, there are marked country-level differences in how academics perceived the importance of ASE activities. Academics in Argentina and, in particular, Portugal were markedly more likely than their peers in Germany and Sweden to state that they saw ASE activities as 'very important'. The exception to this pattern was that Portuguese researchers did not perceive much connection between their ASE activities and their careers, which may be due to the lack of recognition of ASE activities in Portuguese performance assessment systems. In the case of Argentina, there was a striking difference across all three generations between the strong perception of the importance of ASE activities (Table ESM2) and the low level of ASE activities reported (Table 1).

\section{Results of multivariate analysis}

In both Argentina and Portugal, there is almost no evidence of generational differences in the perceptions of the importance of ASE (Tables 3, 4, 5). For Argentina, H1a, H1b, H2a, H2b, H3, and H4 are all rejected. Additionally, the importance of ASE to individual reputation is slightly lower for the post-2006 generation $\left(-0.14^{*}\right)$. This finding is consistent with previous studies on the impact of policies aimed at encouraging academics to build a distinctive academic profile linked to endogenous academic research (Marquina et al., 2017). Concerning the controls, most variables have no significant effect on the importance of ASE activities, except for applied research, time budget, and inter-/multi-disciplinarity on the research dependent variable, where a moderate impact is observed. It should be noted that the overall occurrence of ASE activities in HSS in Argentina was very low compared to other countries, with $<50 \%$ of the academics in the sample reporting having carried out any external activity in recent years. This may be seen as indications of limited overall influence of KE policies in this regard, and may also explain the absence of clear patterns regarding views on ASE in this country.

In Portugal, we observed tendencies toward the post-2006 generation assigning more importance to ASE in terms of their career (support for H2b, Table 4). To a certain extent, this difference may be related to the increased career insecurity and 


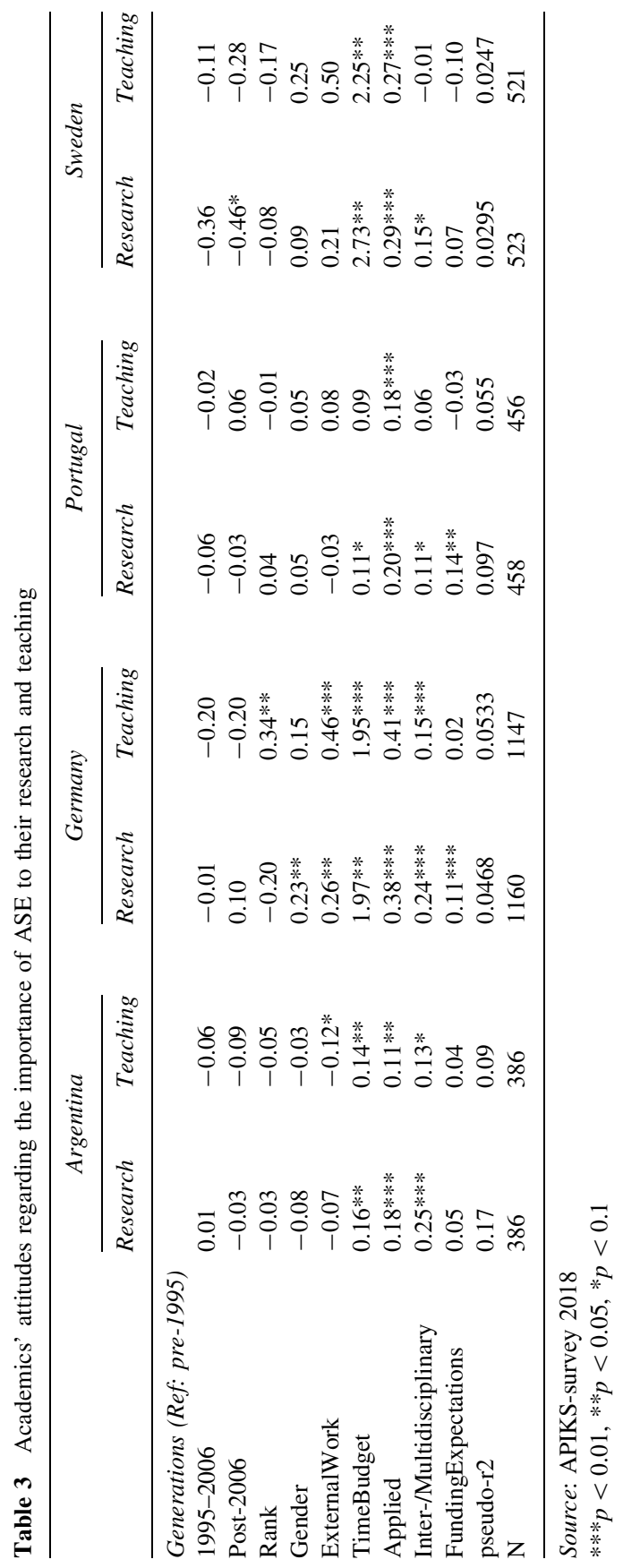


Christian Schneijderberg et al.

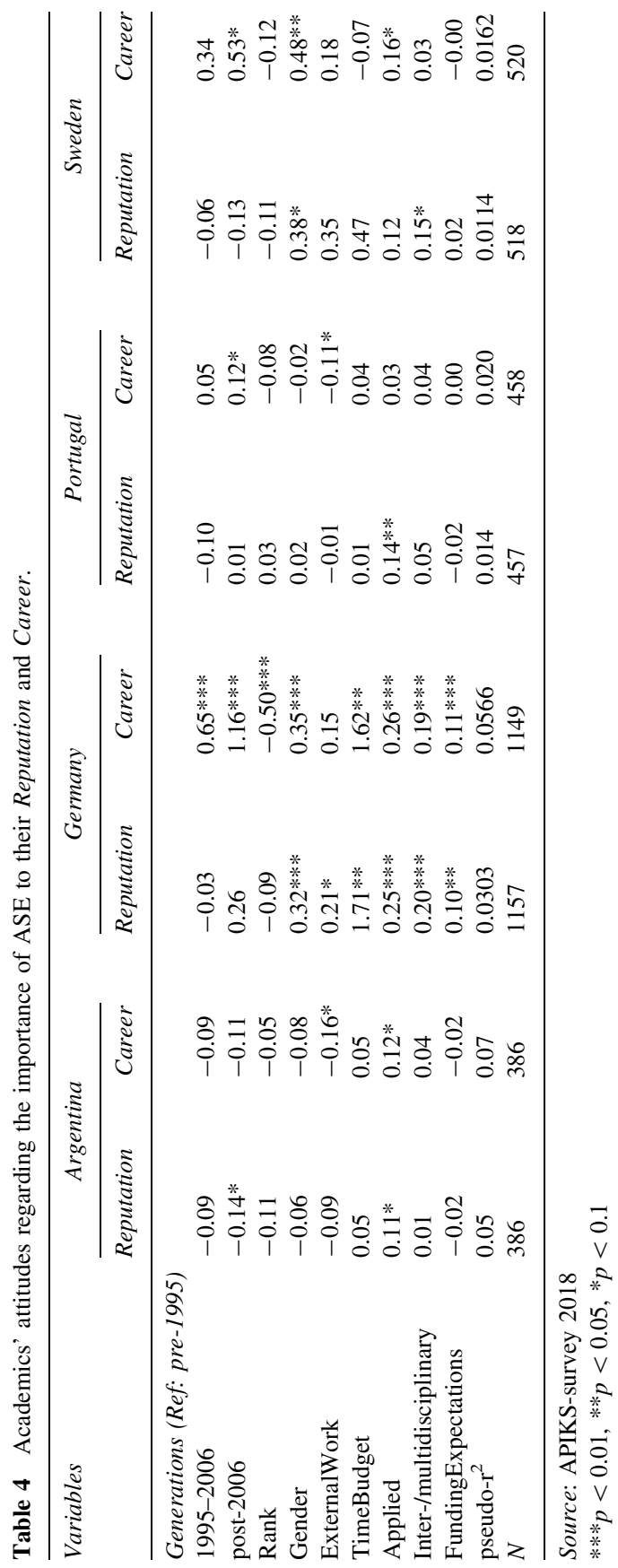




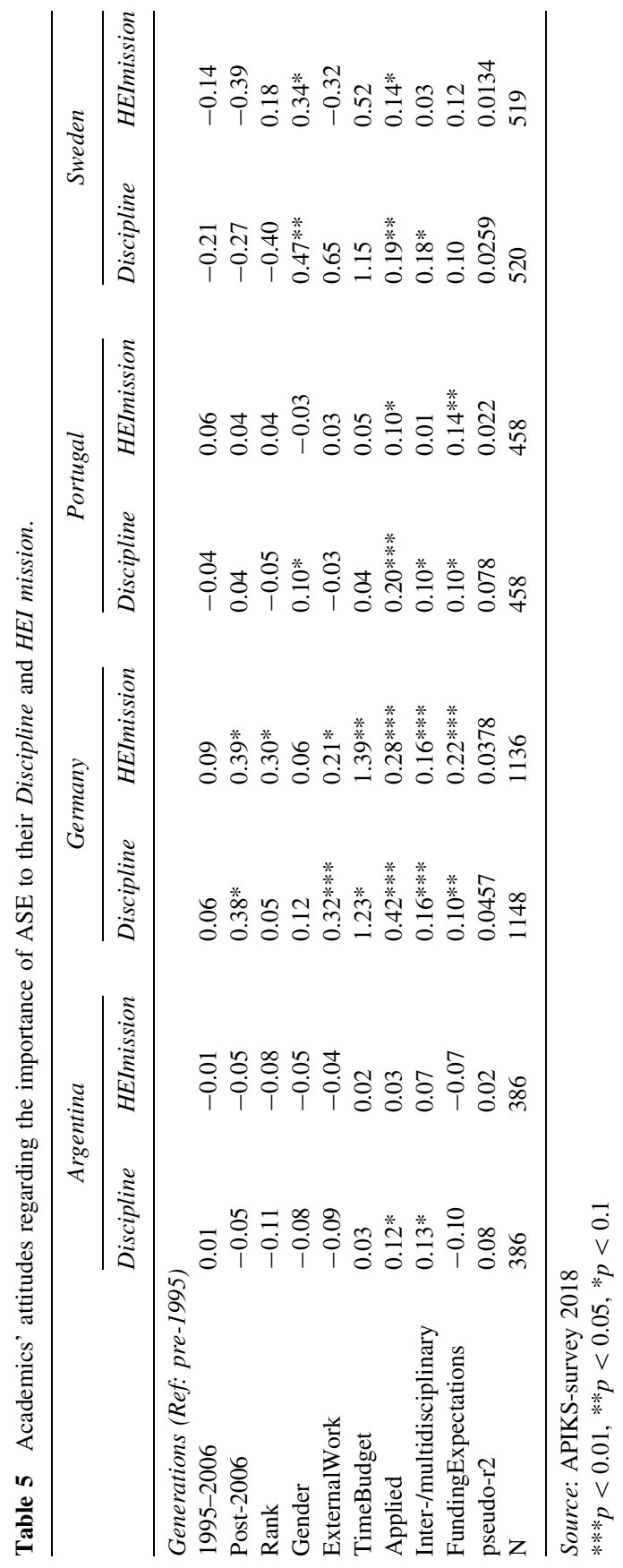


Christian Schneijderberg et al.

degradation of working conditions in Portugal in the last few years (Cardoso et al., 2019). The new generation of academics feels the need to find new opportunities in the labor market, as they also tend to perceive their academic career as less consistent and do not have access to the clear career path that the oldest generation had.

As shown in Table 3, for Germany, we do not observe a greater importance of ASE for the research and teaching work of the post-2006 generation in comparison to the pre-1995 generation (H1a and H1b not accepted). The results appear robust as we do not observe a different result between the pre-1995 and 1995-2006 generations. We observe a positive relationship between academic rank and the perceived importance of ASE for teaching, but not for research. Post-2006 academics were very found to attach greater importance to ASE for their careers, meaning that $\mathrm{H} 2 \mathrm{~b}$ was accepted (Table 4). A corresponding relationship for reputation $(\mathrm{H} 2 \mathrm{a})$ could not be established. Comparing the results from Tables 3-5 with the corresponding models omitting the generation variables (see the Electronic Supplementary Material), we find that disregarding the generational differences would lead to an overestimation of academic rank (Tables ESM3, ESM4 and ESM5).

$\mathrm{H} 3$ and $\mathrm{H} 4$ are also accepted, based on the significant generational differences in the perceived importance of ASE for the development of the discipline and the HEI mission (Table 5). Concerning the controls, the ASE time budget had a significant effect on all dependent variables, while the applied and inter-/multidisciplinary research characteristics had a significant effect on the importance of ASE. Gender effects were observed only for the importance of ASE to research, reputation, and career.

The results for Sweden indicate that academics of the youngest generation are less likely than the older generations to think of their ASE activities as important for their research activities (H1a not accepted). However, there are indications that the less-experienced academics tended to attribute greater weight to their ASE activities with regards to the advancement of their careers (support for $\mathrm{H} 2 \mathrm{~b}$ ). For teaching, individual reputation, development of the discipline, and HEI mission, the results do not show differences between generations in how academics perceived their ASE activities (H1b, H2a, H3, and H4 not accepted).

\section{Discussion of Results and Conclusions}

Across the four HE systems that we investigated, the overall impression was that the introduction of $\mathrm{KE}$ policies has not led to dramatic differences between different generations regarding perceptions of the importance of ASE activities for institutional and disciplinary progress. Comparing the pre-1995 to the post-2006 generation, academics of both generations largely agreed about the importance of 
Christian Schneijderberg et al.

Academics' Societal Engagement in the Humanities and Social Sciences

60

their ASE activities in their institutional and organizational context (i.e., for the development of their discipline and the mission of the HEI where they were employed). In Germany, however, the post-2006 generation considered ASE to be of greater importance for both the mission of their HEI and their discipline. This pattern may reflect German academics' experience of vertical governance initiatives, most notably the Excellence Initiative (e.g., Müller and Schneijderberg, 2020), which aims at strengthening central and departmental HEI management and weakening the chair system.

Our findings suggest that there are no substantial differences in how academics of different generations perceive the importance of ASE for their core activities of teaching and research. The exception is Sweden, where the post-2006 generation was less likely than their elders to think of their ASE activities as important for their research.

Differences between generations were more pronounced concerning the importance of ASE activities for more instrumental aspects of individuals' development. In Germany, Portugal, and Sweden, academics in the youngest generation were more likely than their more seasoned colleagues to think of their ASE activities as important for their careers. In Germany, in particular, the difference between generations, controlling for the full set of covariates, was substantial. No corresponding relationship was found for the Argentinian data. Argentina, however, was the only country in which the young generation deviated from the older generations in their views on how their ASE activities were related to their personal reputation as an academic. This connection was weaker among Argentina's post-2006 academics than among the more experienced cohorts.

Together, these findings would seem to reject expectations that the introduction of KE-rhetoric and policy has led to the implementation of a different mindset among post-2006 scholars. Our data does not support the view that post-2006 scholars in our four countries have learned to center ASE activities in their research and teaching agendas, nor have they more fully embraced ASE activities as key to their disciplinary and institutional development.

The only exception to this was Germany, where there are indications that the post-2006 generation attributes greater weight to ASE activities in terms of their future academic careers. In comparison to the pre-1995 generation, the increasing importance of ASE for individual careers was observable for the transitional 1995-2006 generation and was even stronger for the post-2006 generation. Considering that careers also have a structural, organizational element, we interpret the German findings as evidence that the organizational element, for example stressed by the Excellence Strategy and Rankings, has rapidly influenced individual academics' perceptions of the importance of ASE for their careers. Accordingly, effective policy implementation, such as the linking of compliance with KE policies to research funding, is capable of affecting academics' attitudes in less than 12 years. The effects of KE policies on individual reputation seem to take more 
than 12 years (i.e., the effects of such policies lag by one generation). One explanation for the strong impact of KE-policies is the clear differentiation between non-full professors and full professors, the high level of competition for full professor positions (only 19\% of German academics are full professors; Table ESM6), and the high number of non-full professors on fixed-term contracts (Table ESM7). However, a tenure-track system is slowly developing (BuWiN, 2017). This can be expected to sustain ASE importance, in case ASE is part of the agreement on objectives for tenure evaluation, i.e., the decision of becoming a permanent professor or not.

Taken together, the findings suggest that the post-2006 generation in the four case study countries has not been convinced by KE rhetoric to assign a greater weight to ASE activities than their colleagues with a longer tenure in academia. However, post-2006 academics are more likely to consider ASE activities as relevant from an instrumental perspective. This tendency is perhaps strongest in Sweden, where the post-2006 generation academics in the study were less likely to think of ASE as important for their research, but more likely to consider it important to demonstrate ASE achievements for the further advancement of their career. Rather than seeing a clear shift toward a different type of research, our study indicates that ASE activities have become yet another area where early-career academics experience a need to prove their worth to advance their career.

\section{Acknowledgements}

The authors would like to thank the two unknown reviewers for their helpful and thoughtful suggestions to improve the manuscript. The research in this article was supported in Germany by the Bundesministerium für Bildung und Forschung (Grant M522200); in Sweden by Riksbankens Jublieumsfond (Grant FSK151059:1); in Portugal by the project POCI-01-0145-FEDER-029427- funded by FEDER, through COMPETE2020 - Programa Operacional Competitividade e Internacionalização (POCI), and by national funds (OE), through FCT/MCTES.

\section{Notes}

1. It is important to note that Argentinian undergraduate degrees are not the same as bachelor's degrees. Undergraduate courses last between 5 and 6 years, have an integrated curriculum, and provide students with qualifying degrees for professional practice.

2. Applied and basic as well as disciplinary and inter-/multidisciplinary research characteristics are highly correlated, accordingly, for the ASE case we use only applied and inter-/multidisciplinary. 


\section{Compliance with Ethical Standards}

Conflict of interest On behalf of all authors, the corresponding author states that there is no conflict of interest.

\section{References}

Aagaard, K. and Schneider, J. W. (2016). 'Research funding and national academic performance: Examination of a Danish success story.' Science and Public Policy 43(4): 518-531.

Abreu, M., Grinevich, V. Hughes, A. and Kitson, M. (2009) Knowledge exchange between academics and the business, public and third sectors. Centre for Business Research and UK-IRC. Cambridge: University of Cambridge.

American Association for Public Opinion Research. (2016) Standard definitions. Final dispositions of case codes and outcome rates for surveys.

Andrén, C. G. (2013) Visioner, vägval och verkligheter: Svenska universitetens utveckling efter 1940. [Visions, Route selections and realities: The Development of Swedish Universities after 1940]. Lund: Nordic Academic Press.

APEC - Asia-Pacific Economic Cooperation. (2000). Towards knowledge-based economies in APEC. Seoul: APEC Economic Committee. Available online at: https://www.apec.org/Publications/2000/11/ Towards-KnowledgeBased-Economies-in-APEC-2000. Accessed 15 June 2019.

Arbo, P. and Benneworth, P. (2007) Understanding the regional contribution of higher education institutions. A literature review. Paris: OECD. https://doi.org/10.1787/161208155312.

Austin, A. (2002) 'Preparing the next generation of faculty: graduate school as socialization to the academic career', Journal of Higher Education 73(1): 94-122.

Becher, T. and Trowler, P.R. (2001) Academic Tribes and Territories. Intellectual enquiry and the culture of disciplines (2nd edition). Buckingham: Open University Press.

Benner, M. and Sandström, U. (2000) 'Institutionalizing the triple helix: research funding and norms in the academic system', Research Policy 29(2): 291-301.

Benneworth, P. (ed.) (2013) University engagement with socially excluded communities. Dordrecht: Springer.

Biglan, A. (1973) 'The characteristics of subject matter', Journal of Applied Psychology 57(3): 195-203.

Bronfenbrenner, U. (1979) The ecology of human development. Cambridge: Harvard University Press.

Brennan, J. (2010) 'Burton clark's the higher education system: academic organization in cross-national perspective', London Review of Education 8(3): 229-237.

Cabrito, B. G. (2004) 'Higher education: an education for the elites? The Portuguese case', Higher Education in Europe 29(1): 33-45.

Cardoso, S., Carvalho, T. and Videira, P. (2019) 'Is it still worth working in academia? Portuguese academics' perceptions on the changes in their employment and working conditions', Higher Education Policy 32: 663-679.

Carvalho, T. (2012) 'Shaping the 'new' academic profession. Tensions and contradictions in the professionalisation of academics', in G. Neave and A. Amaral (eds.), Higher Education in Portugal 1974-2009. A Nation, a Generation (pp. 329-352). Dordrecht: Springer.

CEPAL. (1992) Educación y Conocimiento: Eje de la Transformación Productiva con Equidad [Education and knowledge: axis of productive transformation with equity]. Santiago: UN, CEPAL.

Clark, B.R. (1983) The higher education system. Academic organization in cross-national perspective. Berkeley: University of California Press.

de Rijcke, S., Wouters, P.F., Rushforth, A. D., Franssen. T. P. and Hammarfelt, B. (2016) 'Evaluation practices and effects of indicator use - a literature review', Research Evaluation 25(2): 161-169. 
Christian Schneijderberg et al.

Ebbinghaus, B. (2005) 'When less is more: selection problems in large-N and small-N cross-national comparison', International Sociology 20: 133-152.

Edling, C., Farkas, G. and Rydgren, J. (2013) 'Women in power: sex differences in Swedish local elite networks', Acta Sociologica 56(1): 21-40.

Enders, J. and Musselin, C. (2008) 'Back to the future? The academic professions in the 21 st century', in OECD (ed.), Higher Education to 2030: Demography (Volume 1, pp. 125-150). Paris: OECD.

European Commission. (2005) Mobilising the Brainpower of Europe: Enabling Universities to Make Their Full Contribution to the Lisbon Strategy. Brussels: COM(2005) 152 final.

Freidson, E. (2001) Professionalization, the third logic. Chicago: University of Chicago Press.

German Federal Statistical Office (2018a) Personal an Hochschulen [Staff at HEIs]. Wiesbaden.

German Federal Statistical Office (2018b) Hochschulen auf einen Blick [HEIs at a Glance]. Wiesbaden.

Geuna, A. and Muscio, A. (2009) 'The governance of university knowledge transfer: a critical review of the literature', Minerva 47(1): 93-114.

Gläser, J. (2019) 'How can governance change research content? Linking science policy studies to the sociology of science', in D. Simon, S. Kuhlmann, J. Stamm and W. Canzler (eds.), Handbook on Science and Public Policy (pp. 419-447). Cheltenham: Elgar.

Godin, B. (2006) 'The knowledge-based economy. Conceptual framework or buzzword?', Journal of Technology Transfer 31(1): 17-30.

Gorostiaga, J. and Tello, C. (2011) 'Globalización y reforma educativa en América Latina: un análisis inter-textual' [Globalization and educational reform in Latin America: an inter-textual analysis], Revista Brasileira de Educação, 16(47): 363-388.

Grundmann, M. (2006) Sozialisation: Skizze einer allgemeinen Theorie [Socialization: Skech of a general theory]. Konstanz: UVK.

Hartmann, M. (2018). Die Abgehobenen: Wie die Eliten die Demokratie gefährden. Frankfurt: Campus.

Heitor, M. and Horta, H. (2011). 'Science and Technology in Portugal: From Late Awakening to the Challenge of Knowledge-Integrated Communities', in Neave, G. and Amaral, A. (eds.), Higher education in Portugal 1974-2009: A nation, a generation (pp. 179-226). Dordrecht: Springer.

Henningsson, M., Jörnesten, A. and Geschwind, L. (2018) 'Translating tenure track into Swedish: tensions when implementing an academic career system', Studies in Higher Education 43(7): 1215-1226.

Henriques, L. and Larédo, P. (2013) 'Policy-making in science policy: the "OECD model” unveiled', Research Policy 42(3): 801-816.

Hüther, O. and Krücken, G. (2018) Higher Education in Germany - Recent Developments in an International Perspective. Cham: Springer.

BUWIN - Bundesbericht Wissenschaftlicher Nachwuchs. (2017). Bundesbericht Wissenschaftlicher Nachwuchs [Federal Report on Early Career Researchers]. Bielefeld: Bertelsmann.

Link, A. N., Swann, C.A. and Bozeman, B. (2008) 'A time allocation study of university faculty', Economics of Education Review 27: 363-374.

Long, J. S. and Freese, J. (2014) Regression models for categorical dependent variables using stata (3rd edition). College Station: Stata Press.

Lundvall, B.A. (ed.) (1992) National systems of innovation: towards a theory of innovation and interactive learning. London: Pinter.

Marquina, M. (2011) 'Higher education reform in Argentina in the 1990s: paradoxes of government intervention in a minimalist State model', Higher Education Forum 8(3): 93-104.

Marquina, M., Yuni, J. and Ferreiro, M. (2015) 'Generational change in the Argentine academic profession through the analysis of "life courses", Studies in Higher Education 40(8): 1392-1405.

Marquina, M., Yuni, J. and Ferreiro, M. (2017) 'Academic trajectories of generational groups and political context in Argentina: Towards a typology', Education Policy Analysis Archives, 25: 1-23.

Meyer-Krahmer, F. and Schmoch, U. (1998) 'Science-based technologies: University-industry interactions in four fields', Research Policy 27(8): 835-851. 
Christian Schneijderberg et al.

Academics' Societal Engagement in the Humanities and Social Sciences

64

Molas-Gallart, J. and Tang, P. (2011) 'Tracing "productive interactions" to identify social impacts: an example from the social sciences', Research Evaluation 20(3): 219-226.

Müller, L. and Schneijderberg, C. (2020) 'The emergence of the organizational academic profession: Vertical differentiation of German universities and the research-teaching nexus', Higher Education Forum 17, http://doi.org/10.15027/48954.

Numhauser-Henning, A., Ekberg, T. and Sebardt, G. (2007) Karriär för Kvalitet [Careers for Quality]. Stockholm: Fritzes.

Nunes, A. S. (1988). 'Histórias, uma história e a História-sobre as origens das modernas Ciências Sociais em Portugal. [Stories, a story and History - about the origins of modern Social Sciences in Portugal]' Análise Social: 11-55.

Olmos-Penuela, J., Molas-Gallart, J. and Castro-Martinez, E. (2013) 'Informal collaborations between social sciences and humanities researchers and non-academic partners', Science and Public Policy 41(4): 493-506.

Organisation for Economic Cooperation and Development. (1996) The knowledge-based economy. Paris: OECD.

Organisation for Economic Cooperation and Development. (1997) National innovation systems. Paris: OECD.

Paradeise, C., Reale, E. and Goastellec, G. (2009) 'A comparative approach to higher education reforms in western European countries', in C. Paradeise, E. Reale, I. Bleiklie and E. Ferlie (eds.), University Governance. Western European Comparative Perspectives (pp. 197-225). Cham: Springer.

Parsons, T. (1968) 'Professions', in E. Shils (ed.), International encyclopedia of the social sciences (Volume 12, pp. 536-547). New York: Free Press.

Pearson, M. and Brew, A. (2002) 'Research training and supervision development', Studies in Higher Education 27(2): 135-150.

Perkmann, M., King, Z. and Pavelin, S. (2011) 'Engaging excellence? Effects of faculty quality on university engagement with industry', Research Policy 40(4): 539-552.

Perkmann, M., Tartari, V., McKelvey, M., Autio, E., Broström, A., D’Este, P., Fini, R., Geuna, A., Grimaldi, R., Hughes, A., Krabel, S., Kitsong, M., Llerena, P., Lissoni, F., Salter, A. and Sobrero, M. (2013) 'Academic engagement and commercialisation. A review of the literature on universityindustry relations', Research Policy 42(2): 423-442.

Pinheiro, R., Geschwind, L., Hansen, H. F. and Pulkkinen, P. (2019) Reforms, organizational change and performance in higher education: a comparative account from the Nordic Countries. Cham: Palgrave.

Pusser, B. (2008) 'The state, the market and the institutional estate: revisiting contemporary authority relations in higher education', in J. Smart (ed.), Higher Education: Handbook of Theory and Research (Vol. 23, pp. 105-139). New York: Agathon.

Rogers, E. M. (1983) Diffusion of innovation. New York: Free Press.

Ryder, N. B. (1965) 'The cohort as a concept in the study of social change', American Sociological Review 30(6): 843-861.

Sam, C. and van der Sijde, P. (2014) 'Understanding the concept of the entrepreneurial university from the perspective of higher education models', Higher Education 68(6): 891-908.

Santiago, R., Carvalho, T. and Ferreira, A. (2015) 'Changing knowledge and academic profession in Portugal', Higher Education Quarterly 69(1): 79-100.

Schneijderberg, C. (2019) 'Supervision practices of doctoral education and training', Studies in Higher Education, https://doi.org/10.1080/03075079.2019.1689384.

Schneijderberg, C. and Teichler, U. (2012) 'Wissens- und Technologietransfer oder Goldfisch im Kugelglas? [Knowledge and Technology Transfer or a Goldfish in a Glasbubble?]', in Kehm, B. M., Schomburg, H. and Teichler, U. (eds.), Differenzierung, internationalisierung, relevanzsteigerunghochschulen im funktionswandel (pp. 263-280). Frankfurt a.M. and New York: Campus Verlag.

Schneijderberg, C. and Götze, N. (2020; forthcoming) 'Academics' Societal Engagement in Crosscountry Perspective: Large-n in Small-n Comparative Case Studies.' Higher Education Policy. 
Shaw, V. (2005) 'The life course of academic professionals: substantive tasks, false assumptions, institutional accommodations, and personal adjustments', Advances in Life Course Research 9: 331-347.

Seawright, J. and Gerring, J. (2008) 'Case selection techniques in case study research: a menu of qualitative and quantitative options', Political Research Quarterly 61: 294-308.

Smelser, N.J. (2003) 'On comparative analysis, interdisciplinarity and internationalization in sociology', International Sociology 18(4): 643-657.

Thune, T., Reymert, I., Gulbrandsen, M.P. and Aamodt, O. (2016) 'Universities and external engagement activities: particular profiles for particular universities?', Science and Public Policy 43(6): 774-786.

University Policies Secretary. (2020) Synthesis of information from University Statistics 2018-2019. Buenos Aires: DIU.

Wissenschaftszeitvertragsgesetz. (2016) Gesetz über befristete Arbeitsverträge in der Wissenschaft, [Law on fixed-term employment in science] 11 March 2016 (BGB1. I S. 442). Berlin.

World Bank (2002) Constructing knowledge societies. New challenges for tertiary education. Washington DC: World Bank.

Publisher's Note Springer Nature remains neutral with regard to jurisdictional claims in published maps and institutional affiliations.

Electronic supplementary material The online version of this article (https:// doi.org/10.1057/s41307-020-00218-6) contains supplementary material, which is available to authorized users. 